\title{
Metachronous second primary lung cancer surgically treated five years or more after the initial surgery
}

\author{
SATOSHI KOEZUKA ${ }^{1}$, YOSHINOBU HATA ${ }^{1}$, HAJIME OTSUKA ${ }^{1}$, TAKASHI MAKINO ${ }^{1}$, \\ NAOBUMI TOCHIGI $^{2}$, KAZUTOSHI SHIBUYA ${ }^{2}$ and AKIRA IYODA ${ }^{1}$ \\ ${ }^{1}$ Division of Chest Surgery, ${ }^{2}$ Department of Surgical Pathology, \\ Toho University, School of Medicine, Tokyo 143-8541, Japan
}

Received February 12, 2015; Accepted March 20, 2015

DOI: $10.3892 / \mathrm{mco} .2015 .594$

\begin{abstract}
Surgical treatment for metachronous second primary lung cancer following curative resection of primary lung cancer may be challenging. Standard surgical strategies for metachronous second primary lung cancer have not yet been established. The purpose of this study was to evaluate the outcomes of patients who underwent surgical resection for metachronous second primary lung cancer. A total of 12 patients surgically treated for metachronous second primary lung cancer $\geq 5$ years after the initial surgery were retrospectively analyzed. The overall 5-year survival after the second surgery was $56.5 \%$. There was no operative mortality. Patients with T1aN0M0 metachronous second primary lung cancer experienced a significantly higher 5-year overall survival rate compared with other patients (100 vs. $26.7 \%$, respectively; $\mathrm{P}=0.0336)$. Among patients who underwent sublobar resection, all 3 patients with T1aNOM0 disease remained alive at the last follow-up, while 4 of the 5 patients $(80 \%)$ with non-T1aN0M0 disease had developed recurrence. Surgery for metachronous second primary lung cancer may be safely performed. Early-stage metachronous second primary lung cancer was associated with a good prognosis, even among patients who underwent sublobar resection. Early detection of metachronous second primary lung cancer with close long-term follow-up following initial surgery may improve surgical outcomes.
\end{abstract}

\section{Introduction}

Lung cancer is an aggressive malignancy and remains the most common cause of cancer-related mortality worldwide. Pulmonary resection is currently the most effective treatment for patients with non-small-cell lung cancer. However, even if

Correspondence to: Professor Akira Iyoda, Division of Chest Surgery, Toho University, School of Medicine, 6-11-1 Omori-nishi, Ota-ku, Tokyo 143-8541, Japan

E-mail: aiyoda@med.toho-u.ac.jp

Key words: lung cancer, metachronous second primary lung cancer, sublobar resection, recurrence, prognosis patients undergo curative surgical resection for primary lung cancer, they are at risk for developing metachronous second primary lung cancers. The risk of developing a metachronous second primary lung cancer in patients who survive resection of a non-small-cell lung cancer is $1-2 \%$ /patient/year $(1,2)$. The standard surgical treatment for patients with resectable non-small-cell lung cancer is pulmonary lobectomy (3). However, patients with metachronous second primary lung cancer are frequently unable to tolerate lobectomy due to their low cardiopulmonary functional reserve, advanced age and medical comorbidities. There is currently no definitive guideline on surgical therapy for metachronous second primary lung cancer. Metachronous second primary lung cancers are often defined using the criteria proposed by Martini and Melamed (4). These criteria, provided that the histological type is the same as that of the primary lung cancer, comprise the following: A disease-free interval between cancers of $\geq 2$ years; the second cancer originating from carcinoma in situ; first and second primary lung cancers occurring in different lobes, with no carcinoma detectable in the lymph nodes common to both; and no extrapulmonary metastasis present at the time of diagnosis. However, a disease-free interval of at least 2 years is arguable, as chest computed tomography (CT) currently allows for earlier detection of tumors and the incidence of adenocarcinoma has increased (5). Recent studies reported that a disease-free interval of $<2$ or $>2$ years was not associated with survival differences in patients with diagnosed metachronous second primary lung cancer (5-7). In this study, we retrospectively analyzed surgically treated metachronous second primary lung cancers that occurred $\geq 5$ years after the initial surgery.

\section{Materials and methods}

Patients and follow-up. Of the 947 patients who underwent surgical resection for primary lung cancer at our institution between January, 2000 and December, 2012, 12 patients (1.3\%) who underwent second surgery for metachronous second primary lung cancer were enrolled in this study; the interval between the initial and second surgeries was $\geq 5$ years. The pathologists in our hospital confirmed the diagnosis of metachronous lung cancer by examining the surgical specimens from the initial and second surgeries under a microscope. 
More than 5 years after the initial resection of the primary lung cancer, all 12 patients were followed up every 3-6 months. In the outpatient setting, the patients underwent chest X-ray or $\mathrm{CT}$ and evaluation of tumor markers. The following parameters were extracted from medical records: Patient gender, age, tumor size, tumor location, surgical procedure, histological type, pathological TNM stage, time of initial and second surgeries and patient outcome. Survival was calculated from the date of the second resection to the date of the last follow-up or death. All the patients were staged according to the seventh edition of the TNM classification (8).

Statistical analysis. Statistical analysis was performed using JMP software, version 8.0.1 (SAS Institute Inc., Cary, NC, USA). The cumulative survival rates were calculated by the Kaplan-Meier method using the date of second surgery as the starting point. Survival differences were determined by the log-rank analysis. $\mathrm{P}<0.05$ was considered to indicate statistically significant differences.

\section{Results}

Patient characteristics. The study group consisted of 7 men and 5 women. The median age of the patients at the second surgery was 70.5 years (range, 27-83 years). The characteristics of the primary lung cancers are shown in Table I and those of metachronous second primary lung cancers in Table II. The median interval between the first and second surgeries was 10.0 years (range, 5.0-18.0 years). Of the 12 patients, 5 had intervals of $\geq 10$ years from the initial resection of primary lung cancer to the occurrence of metachronous second primary lung cancer. There was no reported intraoperative mortality. Postoperative complications occurred in 4 patients (33\%). A total of 2 patients (16\%) required home oxygen therapy, 1 of whom had suffered acute respiratory failure postoperatively. Two additional complications were atrial fibrillation in 1 patient $(8 \%)$ and heart failure in 1 patient $(8 \%)$. The median follow-up from the date of the second surgery was 28.7 months (range, 6-153 months). The overall 5-year survival rate following resection of metachronous second primary lung cancer was $56.5 \%$ and the median survival was 68.4 months. A total of 5 patients developed tumor recurrence after the second surgery. Among 4 patients who underwent lobectomy or more extensive resections, only 1 patient developed local recurrence. Of the 8 patients who underwent sublobar resection, 3 developed local recurrence and 2 developed distant metastasis, including 1 patient who experienced both. All 4 patients who developed recurrence following sublobar resection for metachronous second primary lung cancer had advanced-stage disease. By contrast, all 3 patients who underwent sublobar resection for T1aNOM0 metachronous second primary lung cancer have been recurrence-free over the 13-153 months after the second surgery.

Survival analysis. The 5-year survival rate was $100 \%$ for patients with stage IA disease and $0 \%$ for patients with higher-stage disease $(\mathrm{P}=0.0067)$ (Fig. 1). The 5-year survival rate was $100 \%$ for patients with T1aNOM0 disease and $26.7 \%$ for patients with non-T1aN0M0 disease ( $\mathrm{P}=0.0336$ ) (Fig. 2). Notably, all the patients with T1aNOM0 disease remain alive
Table I. Patient characteristics at the initial surgery $(n=12)$.

\begin{tabular}{lc}
\hline Characteristics & No. $(\%)$ \\
\hline Gender & \\
Male & $7(58.3)$ \\
Female & $5(41.7)$ \\
Histology of primary lung cancer & \\
Adenocarcinoma & $11(91.7)$ \\
Squamous cell carcinoma & $1(8.3)$ \\
Surgery for primary lung cancer & \\
Lobectomy & $9(75.1)$ \\
Lobectomy + segmentectomy & $1(8.3)$ \\
Bilobectomy & $1(8.3)$ \\
Pneumonectomy & $1(8.3)$ \\
pStage of primary lung cancer & \\
IA & $4(33.4)$ \\
IB & $3(25.0)$ \\
IIA & $1(8.3)$ \\
IIB & $1(8.3)$ \\
IIIA & $3(25.0)$ \\
\hline
\end{tabular}

Table II. Patient characteristics at the second surgery $(n=12)$.

\begin{tabular}{ll}
\hline Characteristics & No. (\%)
\end{tabular}

Age at second surgery, years

Median (range)

$70.5(27-83)$

Interval between first and

second surgery, years

Median (range)

$10.0(5.0-18.0)$

Surgery for second primary lung cancer

Wedge resection

$5(41.7)$

Segmentectomy

$3(25.0)$

Lobectomy

Completion pneumonectomy

$3(25.0)$

$1(8.3)$

Histology of second primary lung cancer

Adenocarcinoma

$10(83.3)$

Squamous cell carcinoma

Site of second primary tumor

Ipsilateral

$4(33.3)$

Contralateral

$8(66.7)$

$\mathrm{T}$ stage of second primary lung cancer

T1a

$6(50.0)$

$\mathrm{T} 1 \mathrm{~b}$

$2(16.7)$

$\mathrm{T} 2 \mathrm{a}$

$3(25.0)$

T3

$1(8.3)$

$\mathrm{N}$ stage of second primary lung cancer

NO

$10(83.4)$

N1

$1(8.3)$

$1(8.3)$

pStage of second primary lung cancer

IA

$7(58.3)$

$3(25.0)$

$2(16.7)$ 


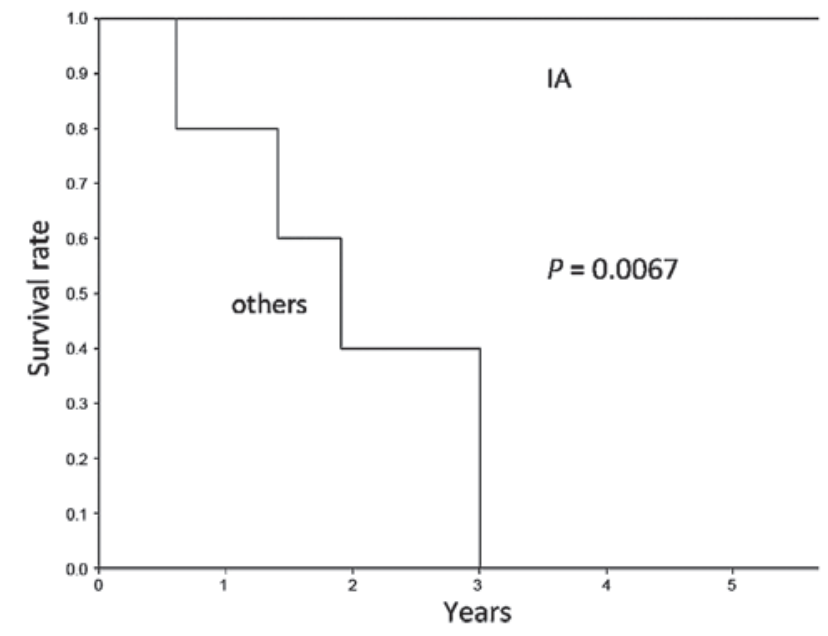

Figure 1. Overall 5-year survival following second surgery among patients with stage IA and higher-stage metachronous second primary lung cancer $(\mathrm{P}=0.0067)$.

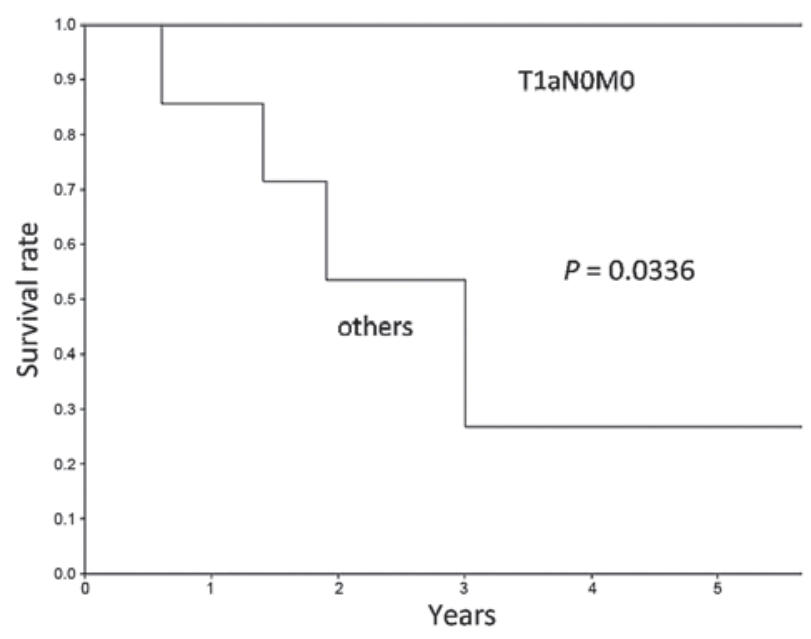

Figure 2. Overall 5-year survival following second surgery among patients with T1aN0M0 and higher TNM stage metachronous second primary lung cancer $(\mathrm{P}=0.0336)$

without recurrence. Patients with early-stage disease exhibited a significantly longer overall survival compared with patients with advanced-stage disease.

\section{Discussion}

Patients who undergo surgical resection of primary lung cancer are at risk for developing metachronous second primary lung cancers. The potential risk of emergence of metachronous second primary lung cancers persists for $\geq 5$ years after the initial surgery for primary lung cancer. In this study, $1.3 \%$ of patients with primary lung cancer developed metachronous second primary lung cancers $\geq 5$ years after the initial surgery. Among the 12 patients, 5 had an interval of $\geq 10$ years between complete resection of the primary lung cancer and the appearance of metachronous second primary lung cancer. Hamaji et al (7) reported that $33.6 \%$ of metachronous second primary lung cancers developed $\geq 5$ years after the resection of the primary lung cancer and $6.9 \%$ developed $\geq 10$ years later.
Asaph et al (9) reported that $38 \%$ of metachronous second primary lung cancers developed $\geq 5$ years following resection of the primary lung cancer.

In the present study, surgery for metachronous second primary lung cancers $\geq 5$ years after the initial surgery for primary lung cancer was performed safely, with a good prognosis for patients with early-stage metachronous second primary lung cancers, even for those who underwent sublobar resection. The overall 5-year survival rate for the second resection was $56.5 \%$, which is similar to previously reported rates $(5-7,10-12)$. The 5-year survival rate following metachronous second primary lung cancer has been reported to range from 26 to $66 \%$ in various series $(5-7,10-12)$. There was no operative mortality in the present study. Regarding the pathological stage of the metachronous second primary lung cancers, patients with stage IA disease had a good prognosis, with a 5-year overall survival rate of $100 \%$. This result is consistent with those of previous reports $(5,10)$.

All the patients with T1aN0M0 disease remained alive at the last follow-up, which ranged from 13 to 153 months. Hamaji et al (7) reported that tumors $\leq 2 \mathrm{~cm}$ in diameter were associated with better survival. The present results indicate that surgery is particularly beneficial for patients with early-stage metachronous second primary lung cancer.

Lobectomy is the standard surgery for primary lung cancer (3). However, patients with metachronous second primary lung cancers occasionally undergo sublobar resection due to their restricted cardiopulmonary functional reserve, advanced age and medical comorbidities. The most suitable surgical approach for metachronous second primary lung cancer has not yet been established. If metachronous second primary lung cancer is located on the same side as the primary tumor, postoperative adhesions may make surgery difficult. In this study, metachronous second primary lung cancer was ipsilaterally located in 4 patients; all the cases had stage IA disease. No patients succumbed to the disease within the first 5 years following surgery. In this study, the type of resection did not predict survival. Among patients who underwent sublobar resection, those with T1aN0M0 disease exhibited a good prognosis. By contrast, other patients tended to have a worse prognosis due to a high rate of tumor recurrence $(80 \%)$. Notably, in the present study, recurrence was observed more frequently in patients who underwent sublobar resection compared to those who underwent more extensive resection. To the best of our knowledge, the number of studies reporting the differences associated with type of resection and tumor recurrence rates following surgery for metachronous second primary lung cancer is currently limited.Zuin et al (13) reported that lobectomy for metachronous and synchronous second primary lung cancer exhibited a statistically significant positive association with survival rate. By contrast, other surgical series reported that type of resection (sublobar vs. more extensive) for metachronous second primary lung cancer did not predict survival $(6,10,11)$. Zuin et al (13) observed no difference in recurrence rates between patients who underwent lobectomy (3.3\%) and those who underwent sublobar resection $(5 \%)$ for metachronous and synchronous second primary lung cancers. The present results indicate that sublobar resection is a safe and effective surgical approach for patients with T1aN0M0 metachronous second primary lung cancer and 
that lobectomy is the most beneficial surgical procedure for patients with non-T1aN0M0 disease.

There is currently no consensus regarding the optimal follow-up strategy long after curative resection of primary lung cancer. The surveillance guidelines and practices vary widely with respect to imaging frequency and modalities (14). Certain studies have suggested that surveillance CT scanning may be effective for the detection of early-stage metachronous second primary lung cancers $(15,16)$. To detect early-stage metachronous second primary lung cancer, prolonged close surveillance for $\geq 5$ years following resection of primary lung cancer is crucial. Even if patients who underwent initial surgery for primary lung cancer have been disease-free for 5 years, long-term follow-up should be considered for early detection of potential metachronous second primary lung cancer. The optimal strategy for long-term follow-up following curative resection of primary lung cancer remains to be determined in future studies.

There were several limitations to this study, mainly its retrospective nature and limited sample size; notwithstanding, we consider the information obtained by this study valuable.

In conclusion, the potential risk of metachronous second primary lung cancer may persist for $\geq 5$ years after the initial surgery for primary lung cancer. Surgery for metachronous second primary lung cancer may be safely performed, with satisfactory outcomes for early-stage metachronous second primary lung cancer. We recommend that close long-term follow-up following surgical resection for primary cancer is continued for early detection of possible metachronous second primary lung cancer to ensure the best possible outcome, even in patients who undergo sublobar resection.

\section{Acknowledgements}

This study was supported in part by a Grants-in-Aid (nos. 24592098 and 26462140) for Scientific Research (C) from the Japanese Ministry of Education, Culture, Sports, Science and Technology.

\section{References}

1. Johnson BE: Second lung cancers in patients after treatment for an initial lung cancer. J Natl Cancer Inst 90: 1335-1345, 1998.
2. Johnson BE, Cortazar P and Chute JP: Second lung cancers in patients successfully treated for lung cancer. Semin Oncol 24: 492-499, 1997.

3. Ginsberg RJ and Rubinstein LV; Lung Cancer Study Group: Randomized trial of lobectomy versus limited resection for T1 N0 non-small cell lung cancer. Ann Thorac Surg 60: 615-623, 1995.

4. Martini N and Melamed MR: Multiple primary lung cancers. J Thorac Cardiovasc Surg 70: 606-612, 1975.

5. Lee BE, Port JL, Stiles BM, Saunders J, Paul S, Lee PC and Altorki N: TNM stage is the most important determinant of survival in metachronous lung cancer. Ann Thorac Surg 88: 1100-1105, 2009.

6. Battafarano RJ, Force SD, Meyers BF, Bell J, Guthrie TJ, Cooper JD and Patterson GA: Benefits of resection for metachronous lung cancer. J Thorac Cardiovasc Surg 127: 836-842, 2004.

7. Hamaji M, Allen MS, Cassivi SD, Deschamps C, Nichols FC, Wigle DA and Shen KR: Surgical treatment of metachronous second primary lung cancer after complete resection of non-small cell lung cancer. J Thorac Cardiovasc Surg 145: 683-691, 2013.

8. Detterbeck FC, Boffa DJ and Tanoue LT: The new lung cancer staging system. Chest 136: 260-271, 2009.

9. Asaph JW, Keppel JF, Handy JR Jr, Douville EC, Tsen AC and Ott GY: Surgery for second lung cancers. Chest 118: 1621-1625, 2000.

10. van Rens MT, Zanen $\mathrm{P}$, de la Rivière $\mathrm{AB}$, Elbers $H R$, van Swieten HA and van den Bosch JM: Survival after resection of metachronous non-small cell lung cancer in 127 patients. Ann Thorac Surg 71: 309-313, 2001.

11. Aziz TM, Saad RA, Glasser J, Jilaihawi AN and Prakash D: The management of second primary lung cancers. A single centre experience in 15 years. Eur J Cardiothorac Surg 21: 527-533, 2002.

12. Haraguchi S, Koizumi K, Hirata T, Hirai K, Mikami I, Kubokura H, Nakajima Y and Shimizu K: Surgical treatment of metachronous nonsmall cell lung cancer. Ann Thorac Cardiovasc Surg 16: 319-325, 2010.

13. Zuin A, Andriolo LG, Marulli G, Schiavon M, Nicotra S, Calabrese F, Romanello P and Rea F: Is lobectomy really more effective than sublobar resection in the surgical treatment of second primary lung cancer? Eur J Cardiothorac Surg 44: e120-e125, 2013.

14. Rubins J, Unger M and Colice GL; American College of Chest Physicians: Follow-up and surveillance of the lung cancer patient following curative intent therapy: ACCP evidence-based clinical practice guideline (2nd edition). Chest 132 (Suppl 3): 355S-367S, 2007.

15. Lou F, Huang J, Sima CS, Dycoco J, Rusch V and Bach PB: Patterns of recurrence and second primary lung cancer in early-stage lung cancer survivors followed with routine computed tomography surveillance. J Thorac Cardiovasc Surg 145: 75-82, 2013.

16. Lamont JP, Kakuda JT, Smith D, Wagman LD and Grannis FW Jr: Systematic postoperative radiologic follow-up in patients with non-small cell lung cancer for detecting second primary lung cancer in stage IA. Arch Surg 137: 935-940, 2002. 